\title{
Risk Analysis of Failure in Sewer Systems in Czech Municipalities
}

\author{
Petr Hluštík ${ }^{1}$, Martina Zeleňáková2* \\ ${ }^{1}$ Institute of Municipal Water Management, Faculty of Civil Engineering, Brno University of Technology, \\ AdMaS Centre, Brno, Czech Republic \\ ${ }^{2}$ Department of Environmental Engineering, Faculty of Civil Engineering, Technical University of Košice, \\ Košice, Slovakia
}

Received: 6 August 2018

Accepted: 21 October 2018

\begin{abstract}
Our paper evaluates the technical condition of sewerage systems in the Czech Republic that are not properly operated and managed. These include municipalities that own the water infrastructure and operate the sewer network themselves. The selected assessed localities are municipalities of up to 1,000 inhabitants in the Czech Republic, which themselves operate sewerage systems aged 40-50 years. The aim of this paper is to compare and classify various defects in the sewerage systems joining risk analysis method and a proposed methodology corresponding to the applicable EN 13508-2 standard used to assess the condition of the sewerage systems and house connections. The evaluation and comparisons of the technical condition of the sewerage systems with the operating companies is the subject of this paper. Evaluation was done by multi-criteria analysis based on the risk analysis method: Failure Mode and Effects Analysis. The results of the assessment of the technical conditions classified into technical indicators of defects are unique in the Czech Republic and abroad.
\end{abstract}

Keywords: sewerage systems, technical condition, defect categories, risk analysis

\section{Introduction}

Currently, various evaluation methodologies are employed to assess the technical condition of the sewer system as well as engineering constructions along with mathematical models and software products that include risk analyses of the operating conditions of the sewers [1-5]. Besides these instruments, a number of European studies have been drawn up to compare various types of pipe systems, i.e., various pipe materials for municipal sewer systems and their impact on the environment over

*e-mail: martina.zelenakova@tuke.sk their service life [6-8]. The optimization problems of water distribution networks also have been investigated [9]. The developed studies usually deal with the specificities of the relevant country as defined by laws and regulations, requirements related to the system operators and control strategies. A public study by Stein and Partner GmbH [10] from Germany compares sewerage failures in European countries and highlights the specificities of each country and differences in the sewerage failures.

The methodology assessing the technical condition of sewerage can be divided into simple and advanced, addressing development strategy and analyses based on models. The mathematical models predicting pipeline 
development are based on probabilistic conditions of the pipelines and on stochastic approaches. The current trend is to simulate sewerage aging using the SemiMarkov chain or to simulate system failures using Monte Carlo algorithms with a fixed time-step, for example the Bietigheim model, KAIN and Pforzheim [11]. The advanced models (software) are used for pipe repair and replacement planning support in the medium to short term. The applied software systems supporting strategic planning are KANEW [12], PiReM - pipe rehabilitation management [13], WARP - water main rehabilitation planner [14], PARMS - pipeline asset and risk management [15], FAST - fichtner asset services and technologies [16], strategy development and analyses model STATUSSewer [11] and other products, including ones that are not publicly accessible and are used internally by various companies.

Most of mentioned approaches used principles of risk analysis, which is widely applied in many fields that touch our daily lives. These include decisions about risks due to chemical and physical stressors (natural disasters, climate change, contaminants in food and water, pollution, etc.), biological stressors (human, plant and animal pathogens; plant and animal pests; invasive species, invasive genetic material), social and economic stressors (unemployment, financial losses, public security, including risk of terrorism), construction and engineering (building safety, fire safety, military applications) and business (project operations, insurance, litigation, credit, etc.) [17]. Risk analysis is a pervasive but often unnoticed component of modern society that is used by governments, the private sector and individuals in the political, scientific, business, financial, social sciences and other communities [18]. There are many studies about risk analysis. Comparison of the most common methods, techniques, methodologies, models, and tools are listed in numerous publications, including [19-25].

The risk analysis and mathematical models of sewer systems are developed in many areas of water engineering, e.g., flood modelling in urban areas, modelling of groundwater infiltration into sewerage systems, modelling for sewage pumping-station [26], modelling of wastewater discharges through combined system [27] overflows in order to protect water resources and ecosystems, models focusing on pipe damage caused by the age of the system, and other advanced models to support planning and rehabilitation of sewerage systems. Risk analysis was also used in [28], where authors assess the incidence of respiratory system disorders among residents in the neighbourhood of a wastewater treatment plant compared to the population living outside the impact area. It can be stated that a data analysis for risk modelling related to wastewater and sewers is specific and complex. Its specificities consist in a lack of data and thus making model calibration for planning rehabilitation of medium and large systems in European countries difficult. Most of the data focuses on local effects caused by secondary conditions.
Data specificities, distortion, model failure in case of limited data and calibration with distorted predictions are described [29]. An appropriate way to meet the calculation requirements using variable grading systems (descriptive, numerical) and units is fuzzy logic. The result of the simulation and model data generation using mathematical models is to define links between local secondary conditions and characteristic specific pipeline failure. The evaluation and comparisons of the technical condition of the sewerage systems within the operating companies in the Czech Republic using the risk analysis method is the subject of this article.

\section{Materials and Methods}

In the Czech Republic, the duty to inspect the structural and technical condition of the sewerage systems is laid down in Act No. 183/2006 Coll. on town planning and the building code (the Building Code) as amended, under which the owners of buildings and water-related structures are obliged to use and operate them in accordance with decisions issued by construction and water authorities, and keep them in good condition [30]. The owner of water-related infrastructure does not carry out these obligations itself, but they are transferred to an operator under an operation contract. Their performance is only possible provided the actual condition of the operated or owned property is established. Thus, the assessment of the structural and technical condition of the sewerage system is not usually the subject of the project assessing the sewerage system, such as a drainage master plan; nevertheless, its results provide important input data for planning the renovation of sewerage systems.

The occurrence and risks of sewerage system defects depend primarily on the quality of design documentation, quality of the applied building materials and the construction of the sewerage system itself, quality of operating the sewerage system and environmental effects (internal and external), which can fundamentally change over the lifetime of the sewerage systems. The defect is a condition when the sewerage system is permanently or temporarily unable to fulfil its function and requirements, with deteriorating reliability of the system compared to its original condition. In extreme situations, the consequences may have a form of emergency breakdown of the sewerage systems, caved-in streets or tramline bodies, subsidence in the worst cases, and even loss of life.

The collection and assessment of all relevant information on the sewerage system and its inspection rank amongst the essential components of operating the sewerage system and form a necessary operation in drawing up sewerage system renewal plans. In the Czech Republic, information about the sewerage system renewal plans are defined under Act No. 274/2001 Coll. on Water Mains and Sewers, as amended [31]. These renewal financial plans force the operators 
Table 1. Definition of categories.

\begin{tabular}{|c|c|c|}
\hline \multicolumn{2}{|c|}{ Code and definition of categories } & Description of measures \\
\hline $\mathrm{CI}$ & Satisfactory condition & No relevant measures to change the indicator are required. \\
\hline $\mathrm{CII}$ & Good condition & No immediate solution is required, renovation within the long-term 15-year plan. \\
\hline $\mathrm{CIII}$ & Unsatisfactory condition & Critical values calling for renovation within the mid-term 5-10 years. \\
\hline $\mathrm{CIV}$ & Emergency condition & Undesirable and malfunctioning condition requiring immediate renovation within 1 year. \\
\hline
\end{tabular}

(owners) of the sewerage systems to develop internal methodologies for assessing the technical condition of the infrastructure.

Assessing the priorities of renewing individual sections of the sewerage systems is usually performed through a categorisation on the basis of a multi-criteria analysis, based on the results of visual inspection and sewerage system monitoring. The choice of the multicriteria evaluation of the sewerage system depends on the operator (owner) of the infrastructure, and it is an internal matter of such a company [32]. However, the content and extent of the internal methodology are always defined by project management and meet the needs of the relevant organisation. Internal assessment methodologies are developed by professionals and are directly applicable to the relevant structures and facilities operated by the company. It may be stated that internal methodologies of the companies are simplified and adequate tools to prevent accidents and bursts, but they are not developed in a transparent way (in particular, there is no emphasis placed on other aspects, for example, competitive facilities in the sewerage system).

According to the focus of analysis, the methods are divided into qualitative and quantitative. However, there are also combined methods (semi-quantitative), allowing qualitative and also quantitative analysis [17]. Failure modes and effects analysis (FMEA) used in this study belong to the qualitative risk analysis method.

\section{Multi-Criteria Analysis of Sewerage Systems}

To classify the individual defects according to applicable standards EN 13508-2: Investigation and assessment of drain and sewer systems outside buildings - Part 2: Visual inspection coding system [33]; the evaluation criteria are proposed for the structural condition of the sewerage system using the failure mode and effects analysis. This is a multi-criteria analysis method that describes systems and subsystems already in the conceptual stage and focuses on interactions between systems and system elements. Potential sewer section failure rate is rated by the highest code (number) of the risk priority. The proposed methodology can be used to detect a potential failure of the system and allocate the necessary time and funds in advance. The groups of defects that are selected as criteria for assessing the technical condition of the sewerage system include:
- $\mathrm{C} 1$ - structural damage to pipes.

- $\mathrm{C} 2$ - damage to internal surfaces.

- $\mathrm{C} 3$ - defected house drain connection.

- C4 - operating defects.

- C5 - sewerage system leakage.

Determining the importance weight for the operator/owner of the sewerage systems is a correction value. Setting the defect importance weight and defect classification into CI-CIV corresponds to the national standards, and it is a recommended value. It is based on the expertise of the author and discussions with the operators of the sewerage systems. The proposed methodology for evaluating defects is easily modifiable for the operators of sewerage systems.

The methodology includes a qualitative systematic list of defects enabling quantification, and also includes an estimate of the worst type of consequence. The description of categories CI-CIV is provided in Table 1.

In mathematical terms, the assessment of the technical condition of the sewer section can be described as follows using Equation 1.

$$
u^{i}=\sum_{j=1}^{n} v_{j} \cdot C_{j}^{i}
$$

...where

$i-1,2 \ldots \mathrm{p}$

$u_{\mathrm{i}}$ - general assessment of $i$-criterion

$v_{j}$ - rate of importance of $j$-criterion

$C_{\mathrm{j}}-i$-sub-assessment of $i$-section based on $j$-criterion

$n$ - number of criteria

$p$ - number of sewer sections

Sections with the highest point scores are proposed to be included in the renovation plans (short-, midand long-term) to renew the sewerage networks and are used as the basis for setting priorities for sewer section rehabilitation. Optimal selection of sections to be renovated is made on the basis of information collected about the structural condition of the sewer, comprehensive assessment of the hydraulic condition of the sewer section, assessment of the impact of the structure on the surrounding environment, etc.

To evaluate the technical condition of the sewer sections using the multi-criteria analysis (Table 2) and to classify the individual defects, it is always necessary to monitor the sewerage system. 


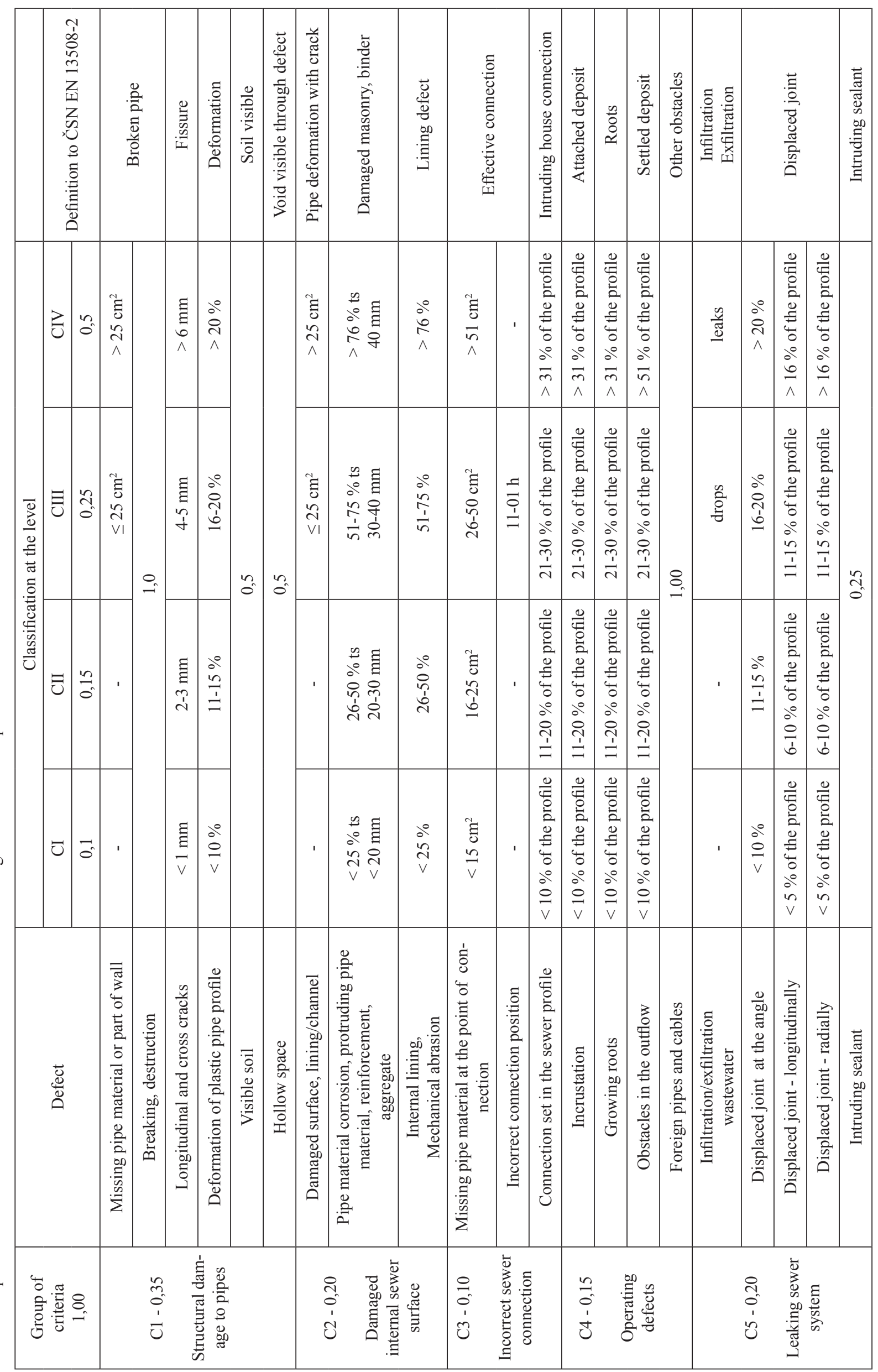


The final assessment values $u_{i}$ are dimensionless figures in an interval of $<0=$ trouble less network, $1=$ necessary rehabilitation $>$. The methodology recommends sections with the highest ranking as sewers to be reconstructed.

\section{Study Area}

The monitoring and evaluation of the technical conditions of the sewerage system according to the proposed selection criteria was conducted in 10 municipalities (systems operated by owner municipalities) in the south Moravian Region and at five municipalities in the Zlín Region in the Czech Republic during 2010-2015. These municipalities have been owners as well as operators of the infrastructure since construction of the sewerage system in the municipality. The major part of the sewerage network was probably built in the 1970s as combined sewerage consisting mainly of concrete or reinforced concrete pipes. In total, the monitoring was conducted over $110 \mathrm{~km}$ of the entire sewerage system in all the municipalities. Statistical data on the sewerage networks in the selected municipalities is given in Table 3.

Based on the size of the assessed municipalities, the sewerage systems can be categorised as 500-2,000 population equivalent. The evaluated data is unique as there is currently no information on the technical condition and defect rate of the sewerage systems operated by the owners - municipalities themselves.

\section{Statistical Evaluation of Data of the Technical Condition of the Several System}

The data of individual technical indicators were evaluated on the basis of camera surveys of the sewerage network. The data for the selected technical indicators are shown in Table 3.

It can be stated that from the structural point of view the most common problem is a damaged or displaced pipe socket joint. Other common problems are hairline cracks, line cracks, fissure lines and open cracks. The displaced connection or connections blockage is caused by improper connection and poorly designed connection gradient to the sewerage network. The connection was often made without the consent of the owner/operator or individually without any special equipment.

In operational terms, the most serious problem is related to the surface damage caused by sulphuric acid corrosion and the related loss of material on the upper surface of the body. The sewer manholes on the sewer networks are often located in the front gardens of detached houses, where they are covered and hidden, which helps develop anaerobic conditions in the sewers. Deterioration of sewer pipe section surface when the sewer manholes are covered over long sections has been observed.

Based on the obtained technical indicator values in all the evaluated municipalities for the same period, we have drawn up the percentage of defects in the sewer system as shown in Fig. 1.

\section{Results}

The unnamed subsidiaries of Veolia Česká Republika, A.S. [34] are represented by companies in Graph A to O. Operators are represented in a range of small municipalities up to large cities. Operators A, $\mathrm{B}$, and $\mathrm{F}$ are cities of more than 100,000 inhabitants, smaller towns and rural areas. Operators C, D, E, H are cities with 50-100,000 inhabitants, smaller towns and rural areas. Operators G, I, J are cities of up to 50,000 inhabitants and rural areas. The letter Z marks selected municipalities that operate sewerage systems themselves. The resulting Fig. 2 shows the overall comparison of the number of defects per $10 \mathrm{~km}$ of sewers of the individual companies and operators (individual municipalities). Fig. 2 shows the resulting comparison of the number of defects per $10 \mathrm{~km}$ of sewers of the individual companies and independent operators of the sewer systems. Currently, no statistical data

Table 3. Statistical expression of failures of sewerage systems.

\begin{tabular}{|c|c|c|c|c|c|}
\hline \multicolumn{6}{|c|}{ Data of selected technical indicators $\mathrm{C} 1-\mathrm{C} 5$ categories CI-CIV } \\
\hline \multirow{2}{*}{ Group of criteria } & \multirow{2}{*}{ Defect } & \multicolumn{4}{|c|}{ Classification at the level (\%) } \\
\hline & & $\mathrm{CI}$ & CII & CIII & CIV \\
\hline \multirow{2}{*}{ C1 - Structural damage to pipes } & Breaking, destruction & 94,3 & 3,2 & 1,5 & 1,0 \\
\hline & Longitudinal and cross cracks & 47,3 & 36,6 & 12,0 & 4,0 \\
\hline C2 - Damage internal sewer surface & $\begin{array}{c}\text { Pipe material corrosion, protruding pipe material, } \\
\text { reinforcement }\end{array}$ & 25,3 & 62,2 & 10,4 & 2,1 \\
\hline C3 - Incorrect sewer connection & Connection set in the sewer profile & 72,8 & 20,2 & 5,3 & 1,8 \\
\hline \multirow{2}{*}{ C4 - Operating defect } & Obstacles in the outflow & 52,9 & 32,3 & 10,0 & 4,8 \\
\hline & Growing roots & 80,2 & 18,5 & 1,1 & 0,2 \\
\hline C5 - Leaking sewer system & Displaced joint - longitudinally & 36,4 & 37,1 & 21,8 & 4,7 \\
\hline
\end{tabular}



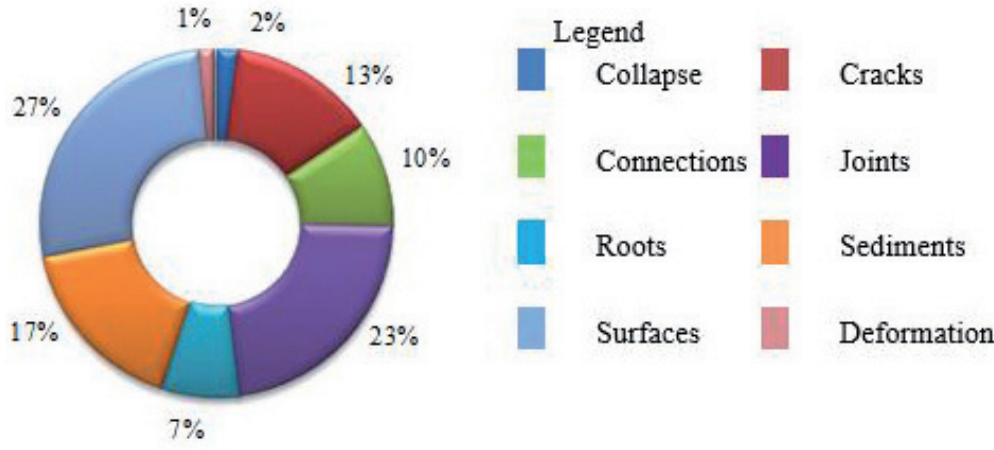

Fig. 1. Types of defects and their occurrence in sewerage.

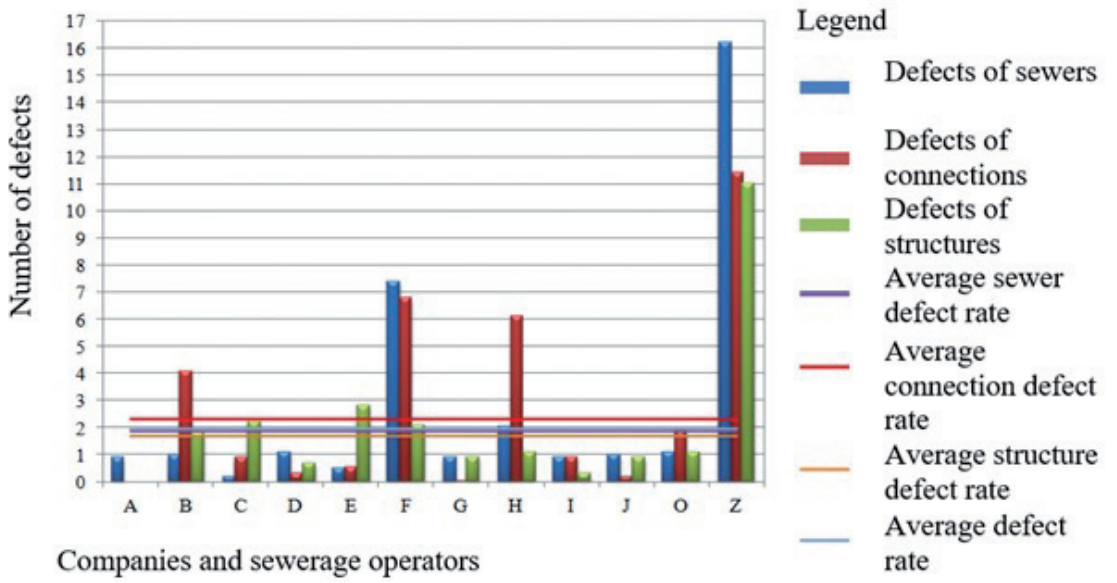

Fig. 2. Average number of defects per $10 \mathrm{~km}$.

providing a comprehensive comparison of the number of defects and their percentage is available in the Czech Republic.

As regards concrete pipes, this concerns smallersize sewers made of plain concrete used in the past for the construction of sewerage systems in small municipalities, and which are presently at the end of their service life. The defect rate of stoneware and plastic pipes is only aiming as stoneware pipes have been used in the Czech Republic for more than 100 years, while plastic pipes have been used for a much shorter period of time.

When comparing the defect rates of the individual types of piping materials in company $\mathrm{Z}$, we also take into account the time factor, i.e., comparison of the defect rate of sewers of the same age. Defects of the sewerage system were caused by lack of qualification in constructing the sewerage systems involving local residents, the age of the sewerage system and use of lower quality materials during construction conducted in the past. Experience shows that the assessed selected municipalities do not carry out regular inspections and maintenance of sewers, i.e., CCTV (closed circuit television) inspections nor physical visual inspection of structural and technical conditions. The average defect rate of the sewerage systems in comparison with the subsidiaries of Veolia Czech Republic is up to 5 times higher, totalling an average of 13 defects per

Table 4. Statistical data on rural communities in the Czech Republic operated by the municipalities.

\begin{tabular}{|c|c|c|c|c|c|}
\hline \multicolumn{6}{|c|}{ Statistical data of the evaluated municipalities in the Czech Republic operated by the municipalities } \\
\hline Material & $\mathrm{km}$ & $\%$ & Profile $[\mathrm{mm}]$ & $\mathrm{km}$ & $\%$ \\
\hline Stoneware & 23,4 & 21,3 & $<300$ & 51,8 & 47,1 \\
\hline Concrete & 50,5 & 45,9 & $301-500$ & 35,6 & 32,4 \\
\hline Plastics & 29,8 & 27,1 & $501-800$ & 15,2 & 13,8 \\
\hline Others & 6,3 & 5,7 & $>800$ & 7,4 & 6,7 \\
\hline
\end{tabular}


$10 \mathrm{~km}$. The evaluated municipalities do not develop water infrastructure renewal plans, they have no overview of the sewerage facility records and they do not generate financial reserves or funds for maintenance, repairs, renovation or reconstruction of the sewerage network and sewerage-related structures. The aforementioned reasons have made the municipal councils in $40 \%$ of the assessed municipalities change the operators, usually being replaced with regional water utilities in the relevant regions of the Czech Republic. The comparison of the individual indicator defaults was carried out with the Veolia Česká Republika, a leading supplier of water-related services that provides sewerage services to more than 3.2 million inhabitants.

This company has published statistical information on the average defect rate of the sewerage systems and facilities of its subsidiaries, which are compared with the results of the sewerage operated by their owners (Table 4).

\section{Conclusions}

The reason for postponing repairs today is presently often the lack of funds available to the operator (owner) for repairs, which is a frequent problem of a vast majority of the operators. The sewerage system repairs necessitated by defects form a significant cost item of each and every operator and are a factor affecting the sewage tariff level. Each operator makes surveys of the sewerage system in their own interest, and they keep records of defects and their monitoring. The survey results are an invaluable source of information on the types and characteristic defects related to the individual sewer material groups, civil structures in the system, causes of the defects and frequency of defects in the system.

This paper offers an alternative solution for assessing the structural and technical condition of sewer systems using a multi-criteria analysis based on the failure mode and effects analysis method while keeping the relative assessment scale and comparing the results. This method has been implemented in selected municipalities of the Czech Republic, which themselves operate their sewerage systems and know their technical condition. The results of assessing the technical conditions classified into technical indicators of defects are unique both in the Czech Republic and abroad. The uniqueness of the results consists of the percentage classification of the individual failures in the relevant categories. For the water infrastructure self-operators there are currently no statistical data for classifying the individual failures. The self-operators have no overview of the technical condition of the sewerage systems because they usually do not perform system maintenance and they only handle any potential failures or bursts. Currently, water companies operating water infrastructure do not develop and classify any detailed statistical data of the sewer system defects. Internal databases of these companies provide information about sewerage CCTV inspections indicating defects; however, these defects are not further analysed or classified.

The conducted analysis has determined the average defect rate of sewerage systems for selected municipalities operating their sewerage networks themselves, and the data was compared with Veolia Česká Republika. The empirical experience is not recorded and is usually included in internal documents.

The CCTV inspections in selected municipalities can be comprehensively compared. The sewerage construction took place over the same years, and the material used is of the same age - just like the construction of the sewerage. The CCTV inspections were conducted in all parts of the sewerage system of the selected municipalities and therefore no random selection was made. For the duration of the CCTV inspections we can ignore the newly formed defects following the sewerage monitoring, which could affect the statistical data. The final analysis of the evaluated municipalities did not reveal any link between a defected pipe and local ecological and environmental conditions of the landscape.

The measured data can be integrated into the pipe aging model and the forecasting model.

\section{Acknowledgements}

This paper has been worked out under project No. LO1408 "AdMaS UP: Advanced Materials, Structures and Technologies," supported by the Ministry of Education, Youth and Sports under the National Sustainability Programme I.

\section{Conflict of Interest}

The authors declare no conflict of interest.

\section{References}

1. FREY D.D., HERDER P.M., WIJNIA Y., SUBRAHMANIAN E., KATSIKOPOULOS K., DE NEUFVILLE R., OYE K., CLAUSING D.P. Research in engineering design: the role of mathematical theory and empirical evidence. Research in Engineering Design, 21 (3), 145, 2010.

2. EISENBART B., GERICKE K., BLESSING L.T.M., MCALOONE T.M. A DSM-based framework for integrated function modelling: concept, application and evaluation Research in Engineering Design, 28 (1), 25, 2017.

3. IC Y.T. Development of a new multi-criteria optimization method for engineering design problems. Research in Engineering Design, 27 (4), 413, 2016.

4. LIANG R., DONG Z., SHENG Y., WANG X., WU Ch. Case Study of Selecting Decision-Making Schemes 
in Large-Scale Infrastructure Projects. Journal of Infrastructure Systems, 23 (4), 2017.

5. ARIARATNAM S.T., EL-ASSALY A., YANG Y. Assessment of infrastructure inspection needs using logistic models. Journal of Infrastructure Systems, 7 (4), 160, 2001.

6. HOCHSTRATE K. Substanzwertorientierte Zustandsklassifizierung von Kanälen: Das Modell Bietigheimer. KA. Korrespondenz Abwasser, 46 (2), 213, 1999.

7. WALDMANN K.H., STOCKER U.M. Stochastische Modelle: Eine anwendungsorientierte Einführung. Springer-Verlag: Berlin Heidelberg, Germany. ISBN 9783-540-03241-0, 2004 [In German].

8. SCHMIDT T. Modellierung von Kanalalterungsprozessen auf der Basis von Zustandsdaten. Dissertation. Technischen Universität Dresden, Fakultät für Bauingenieurwesen, Institut für Stadtbauwesen und Straßenbau. 2009 [In German].

9. RUIZ-VANOYE J.A., BARRERA-CÁMARA R., DÍAZPARRA O., FUENTES-PENNA A., PÉREZ ORTEGA J., BERNABE LORANCA B., CANEPA SAENZ A., SANTIAGO-PÉREZ J.C. Surveying the Optimization Problems of Water Distribution Networks Pol. J. Environ. Stud. 27 (4), 1425, 2018.

10. STEIN D. Final Report: European study of the performance of various pipe systems, respectively pipe materials for municipal sewage systems under special consideration of the ecological range of effects during the service life. Partner GmbH: Bochum, Germany, 2005.

11. Evaluation models for the assessment of the structural and operational condition of drain and sewer systems. Available online: http://www.unitracc.com/aktuelles/ artikel/evaluation-models-for-the-assessment-of-thestructural-and-operational-condition-of-drain-and-sewersystems-2015-part-iii. (Accessed on 12 November 2016).

12. KROPP I., BAUR R. Integrated failure forecasting model for the strategic rehabilitation planning. Water Science and Technology: Water Supply, 5 (2), 1, 2005.

13. FUCHS-HANUSCH D., GANGL G., KORNBERGER B., KÖLBL J., HOFRICHTER J., KAINZ H. PiReMPipe Rehabilitation Management Developing a Decision Support System for Rehabilitation Planning of Water Mains. Water Practice and Technology, 3 (1), 1, 2008.

14. CARDOSO M.A., SILVA M.S., COELHO S.T., ALMEIDA M.C., COVAS D.I. Urban water infrastructure asset management - A structured approach in four water utilities. Water Science and Technology, 66 (12). ISSN 2702-2711, 2012.

15. BURN S., TUCKER S., RAHILLY M., DAVIS P., JARRETT R., PO M. Asset planning for water reticulation systems - the PARMS model. Water Science \& Technology: Water Supply, 3 (1-2), 55, 2003.

16. SCHOLTEN L., SCHEIDEGGERA A., REICHERTA P., MAURERA M., LIENERT J. Strategic rehabilitation planning of piped water networks using multicriteria decision analysis. Water Research, 49, 124, 2014.

17. ZELEŇÁKOVÁ M., ZVIJÁKOVÁ L. Using Risk Analysis for Flood Protection Assessment. Springer International
Publishing: Switzerland. ISBN 978-3-319-52149-7, 128, 2017.

18. ARTHUR J.R., BONDAD-REANTASO M.G. Introductory training course on risk analysis for movements of live aquatic animals. FAO SAP, Samoa, 167, 2012.

19. ALVERBRO K., NEVHAGE B., ERDENIZ R. Methods for risk analysis. Sweden by US AB, Stockholm. ISSN 1652-5442. 2010.

20. MARHAVILAS P., KOULOURIOTIS D., GEMENI V. Risk analysis and assessment methodologies in the work sites: on a review, classification and comparative study of the scientific literature of the period 2000-2009 Journal of Loss Prevention in the Process Industries, 24 (5), 477-, 2011.

21. RASCHE T. Risk analysis methods - a brief review. The University of Queensland. Mineral Industry Safety and Health Center, 2001.

22. RASPOTNIG CH., OPDAHLA A. Comparing risk identification techniques for safety and security requirements. Journal of Systems and Software 86 (4), 11241, 2013.

23. RENIERS G.L., DULLAERT W., ALE B.J.M., SOUDAN $\mathrm{K}$. Developing an external domino prevention framework: Hazwim. Journal of Loss Prevention in the process industries, 18 (3), 127, 2015.

24. ROUVROYE J.L., VAN DEN BLIEK E.G. Comparing safety analysis techniques. Reliability Engineering \& System Safety, 75 (3), 289, 2002.

25. SEGUDOVIC H. Qualitative risk analysis method comparison. Infigo IS d.o.o., Zagreb, 2006.

26. SLYŚ D., DZIOPAK J. Development of mathematical model for sewerage pumping-station in the modernized combined sewage system for the town of Przemyśl. Polish Jurnal of Enviromental Studies. 20 (3), 743, 2011.

27. SLYŚ D., STEC A. Hydrodynamic modelling of the combined sewage system for the city of Przemyśl. Environment Protection Engineering. 38 (4), 99, 2012.

28. JAREMKÓW A., NOGA L., PAWLAS K. Respiratory System Symptoms in the Neighborhood of a Wastewater Treatment Plant. Pol. J. Environ. Stud. 27 (1), 117, 2018.

29. SCHEIDEGGER A., SCHOLTEN L., MAURER M., REICHERT P. Extension of pipe failure models to onsider the absence of data from replaced pipes. Water Research, 47 (11), 3696, 2013.

30. Act No. $183 / 2006 \mathrm{Sb}$. on town planning and the building code (the Building Code). The Czech Republic: AION, c2010-2016, Volume 2006, no.183, 2006.

31. Act No. 274/2001 Sb. on Water Mains and Sewers. The Czech Republic: AION, c 2010-2016, Volume 2001, no. 274, 2001.

32. HLUŠTÍK P., NOVOTNÝ J. The Testing of Standard and Recyclable Filter Media to Eliminate Hydrogen Sulphide from Sewerage Systems. Water, 10 (6), 689, 2018.

33. EN 13508-2 Evaluation of condition of outside sewer network system and sewer hook- ups. Part 2.Coding system for visual inspection. CEN, c2012, 2012.

34. Veolia Czech Republic: Veolia, Available online: http:// www.veolia.cz/cs. Accessed on 8 August 2016. 